\title{
АНАЛІЗ СИСТЕМИ ЗАБЕЗПЕЧЕННЯ ІНФОРМАЦІЙНОЇ БЕЗПЕКИ
}

Рогова $\epsilon$. I.

У статmі проведено аналіз системи забезпечення інформаційної безпеки як інструмента реалізації державної політики інформаційної безпеки, яка $\epsilon$ і похідною, $і$ детермінованою напрямами державної інформаційної політики. 3 урахуванням цього надано характеристику основних структурних елементів системи забезпечення інформаційної безпеки. Проаналізовано основні повноваження та функції елементів системи забезпечення інформаційної безпеки України. Визначено головні складники забезпечення інформачійної безпеки держави.

Ключові слова: інформація, інформаційна безпека, система забезпечення інформаційної безпеки, інформаційне суспільство, інформаційний простір.

В статье проведен анализ системы обеспечения информационной безопасности как инструмента реализации государственной политики информационной безопасности, которая является и производной, и детерминированной направлениями государственной информационной политики. С учетом этого охарактеризованы основные структурные элементы системы обеспечения информационной безопасности. Проанализированы основные полномочия и функции элементов системы обеспечения информационной безопасности Украины. Определены главные составляющие обеспечения информационной безопасности государства.

Ключевые слова: информация, информационная безопасность, система обеспечения информационной безопасности, информационное общество, информационное пространство.

The article analyzes the information security system as a tool for implementing the state information security policy, which is both a derivative and deterministic direction of the state information policy. In view of this, the main structural elements of the information security system are characterized. The following conclusions are drawn. In protecting their information interests, every state should take care of its information security. This also requires the strengthening of Ukrainian statehood. The balanced state information policy of Ukraine is formed as an integral part of its socio-economic policy, based on the priority of national interests and threats to the national security of the country. From a legal point of view, it is based on the rule of law and is implemented through the development and implementation of relevant national doctrines, strategies, concepts and programs in accordance with applicable law. In Ukraine, there is an objective need for state-legal regulation of scientific and technological activities and information activities, which would correspond to the realities of the modern world and the level of development of information technologies, the norms of international law, but at the same time would effectively protect their own Ukrainian national interests. Relationships related to information security, as crucial for society and the state today, require the fastest possible legislative regulation.

Successful information policies can have a significant impact on the resolution of domestic, foreign and military con-

Рогова Є. І., 2019 flicts. Information security is one of the essential components of the national security of the country, and its support through consistent implementation of a well-formulated national information strategy would greatly contribute to achieving success in solving problems in political, social, economic and other spheres of state activity.

At the same time, the article explores a number of legal acts, in particular, the Constitution of Ukraine, the Law of Ukraine "On the Basics of National Security of Ukraine", "On Information Sovereignty and Information Security of Ukraine", "On Information", "On Print Media (Press) in Ukraine", "On Television and Radio Broadcasting", "On Copyright and Related Rights", "On State Secrets", "On Protection of Information in Automated Systems" and others.

Positions of authoritative legal scholars such as M. Gutsalyuk, O. Dovgan, V. Luzhetsky, O. Onischenko, V. Shatun and others were studied. The author identifies the main objects of the information security system: the state, and in particular its constitutional system, sovereignty, territorial integrity, political, economic and social stability, law and order, international cooperation, etc.); society (democracy, culture, spiritual and historical heritage, information resources, social cohesion, political stability, etc.); man and citizen (life, health, culture, traditions, etc.). The author also distinguishes the subjects of this system: the state (institutions, officials), society (social groups and groups, public organizations), as well as individual citizens.

The purpose of information security is defined in the article - it is prevention of misconduct with information resources and systems; ensuring the proper state of information; protecting the rights and ensuring the legitimate interests of the subjects of the information sphere. The article contains a list of functions of information security system of Ukraine: creation and maintenance of activity of all elements of information security system; management of this system; planned and operational activities to ensure it; international cooperation. And also - methods of providing information security: single-level, multi-level, integrated, integrated.

The principles (based on the content of the Information Security Doctrine of Ukraine) are analyzed: freedom to collect, store, use and disseminate information; the accuracy, completeness and impartiality of information; restricted access; harmonization of interests; offense prevention; economic feasibility; harmonization of legislation; the priority of national information products.

Key words: information, information security, information security system, information society, information space.

Постановка проблеми та її актуальність. Проблема захисту національного інформаційного простору в умовах становлення сучасного інформаційного суспільства $\epsilon$ основою вдосконалення соціальної структуризації суспільства, джерелом суспільного прогресу. Інформація - це основа безпечного та раціонального розвитку сучасного інформаційного суспільства. Водночас інформація може слугувати зброєю, яка впливає на світогляд людини, населення, формує негативне ставлення до певних явищ, до держави та суспільства загалом, викривляє факти й події, що впливає на якість та ефективність сучасних реформ у суспільстві тощо. 
Аналіз останніх досліджень і публікацій. Питання системи забезпечення інформаційної безпеки України висвітлювалося в наукових працях таких вітчизняних і зарубіжних авторів, як І. Арістова, В. Бебик, А. Гальчинський, О. Голобуцький, П. Друкер, Я. Жаліло та інші.

Метою статті $\epsilon$ ґрунтовний аналіз системи забезпечення інформаційної безпеки.

Виклад основного матеріалу. Систему забезпечення інформаційної безпеки О. Тихомиров будує так:

1. За сферами суспільного життя (в економічній, політичній, воєнній, науково-технологічній, екологічній, соціальній сфері тощо);

2. За об'єктами національної безпеки (забезпечення інформаційної безпеки особи, суспільства та держави);

3. За сучасними аспектами розуміння інформаційної безпеки (у сфері прав і свобод людини та інформаційно-технічної, у т. ч. кібернетичної безпеки);

4. За основними видами діяльності (забезпечення законних можливостей створення, збирання, одержання й використання інформації, законного порядку поширення інформації, належного зберігання інформації);

5. За формами державного забезпечення інформаційної безпеки (забезпечення якісного інформування, процесів інформатизації; правова регламентація сфери інформаційнихвідносин; боротьбазправопорушеннями);

6. За напрямами пізнавального процесу в галузі забезпечення інформаційної безпеки (професійна освіта, наукові дослідження, інформаційно-просвітницька діяльність тощо) [1, с. 497-502].

Основними об'єктами системи забезпечення інформаційної безпеки є національні цінності, цілі, інтереси, тому що вона складник національної безпеки. Виходячи із цього, іiї об'єктами є держава (зокрема їі конституційний лад, суверенітет, територіальна цілісність, політична, економічна та соціальна стабільність, законність i правопорядок, міжнародне співробітництво тощо); суспільство (демократія, культура, духовно-історична спадщина, інформаційні ресурси, суспільна злагода, політична стабільність тощо); людина та громадянин (життя, здоров'я, культура, традиції тощо). Суб'єктами цієї системи є держава (інститути, посадові особи), суспільство (соціальні верстви та групи, громадські організації), а також окремі громадяни [2, с. 92-95].

Виділимо основні функції системи забезпечення інформаційної безпеки України: створення й забезпечення діяльності всіх елементів системи забезпечення інформаційної безпеки; управління цією системою; планова та оперативна діяльність щодо ії забезпечення; міжнародне співробітництво.

Забезпечення інформаційної безпеки України здійснюється за такими принципами:

1. Свобода збирання, зберігання, використання й поширення інформації;

2. Достовірність, повнота й неупередженість інформації;

3. Обмеження доступу до інформації виключно на підставі закону;

4. Гармонізація інтересів;

5. Запобігання правопорушенням в інформаційній сфері;

6. Економічна доцільність;

7. Гармонізація українського законодавства в інформаційній сфері з міжнародним;
8. Пріоритетність національної інформаційної продукції [3, с. 155-161].

Проаналізуємо основні повноваження й функції елементів системи забезпечення інформаційної безпеки України:

громадяни України (на виборах, референдумах, через органи державної влади та місцевого самоврядування). Вони можуть висловлювати й реалізувати свої бачення в інформаційній сфері, у системі їі захисту, можуть привернути іï увагу до небезпеки, захищати свої права й інтереси в інформаційній сфері всіма законними способами та засобами;

Верховна Рада України - здійснює законодавче регулювання у сфері інформаційної безпеки, затверджує державний бюджет, де передбачаються кошти на забезпечення системи інформаційної безпеки, схвалює національні програми розвитку інформаційної сфери; призначає 4 особи Національної Ради України з питань телебачення і радіомовлення тощо;

профільний парламентський Комітет з питань свободи слова та інформації - готує законопроекти з питань інформаційної політики й безпеки;

Комітет з питань будівництва, транспорту i зв'язку - уносить законодавчі пропозиції з питань функціонування та розвитку системи зв'язку (елементу інформаційної інфраструктури);

Президент України - здійснює керівництво у сфері інформаційної безпеки, звертається зі щорічними (позачерговими) посиланнями до Верховної Ради про стан інформаційної безпеки; призначає та звільняє з посад керівників міністерств, державних комітетів, інших центральних органів виконавчої влади, що мають повноваження в інформаційній сфері, а також керівника Державної служби спеціального зв'язку та захисту інформації й нового складу Національної Ради України з питань телебачення і радіомовлення (4 особи).

Адміністрація Президента України - їй підпорядкований Національний інститут стратегічних досліджень, він здійснює координацію досліджень з питань інформаційної безпеки;

Рада національної безпеки і оборони (РНБО) України - очолює глава держави, вона координує й контролює діяльність органів виконавчої влади у сфері інформаційної безпеки; подає главі держави пропозиції щодо стратегічних інтересів України у сфері забезпечення інформаційної безпеки, заходів відповідно до потенційних і реальних загроз національним інтересам України;

Кабінет Міністрів України - забезпечує державний суверенітет, виконання Конституції й законів України, актів Президента України в інформаційній сфері; уживає заходів щодо забезпечення інформаційної безпеки, боротьби зі злочинністю в інформаційній сфері;

Урядова комісія з питань інформаційно-аналітичного забезпечення діяльності органів виконавчої влади - розробляє пропозиції щодо реформування системи інформаційно-аналітичного забезпечення діяльності органів виконавчої влади;

міністерства - забезпечують виконання всіх законодавчих і нормативних актів в інформаційній сфері;

міністерство освіти і науки України - забезпечує реалізацію державної політики у сфері освіти, наукової, науково-технічної, інноваційної діяльності, інтелектуальної власності, авторського права; 


\section{адміністративної реформи}

Державний комітет інформаційної політики, телебачення і радіомовлення України - уносить пропозиції щодо державної політики в інформаційній і видавничій сферах; координує діяльність державних засобів масової інформації; здійснює заходи щодо захисту інформаційного простору України;

Державний комітет зв'язку та інформації України - удосконалює національну систему зв'язку; формує національну програму інформатизації та контролює іï виконання;

Державний комітет архівів України - координує архівну справу й діловодство; несе відповідальність за її стан і розвиток;

Державна служба спеціального зв'язку та захисту інформації - забезпечує захист інформаційних ресурсів у мережах передачі даних, реалізує державну політику у сфері криптографічного й технічного захисту інформації;

Національна рада України з питань телебачення i радіомовлення - забезпечує свободу слова та масової інформації (звукової, візуальної, аудіовізуальної); ліцензує телерадіомовлення; контролює використання радіочастотного ресурсу держави й виконання законодавства України у сфері телебачення і радіомовлення;

Конституційний Суд України - вирішує питання про відповідність законів, інших правових актів в інформаційній сфері Конституції України, дає тлумачення Конституції та законів України щодо відповідних питань;

суди загальної юрисдикції - здійснюють правосуддя у сфері інформаційних відносин;

Генеральна прокуратура України - здійснює нагляд за дотриманням і застосуванням законів, що регулюють інформаційні відносини, порушує кримінальні справи;

обласні державні адміністрації - забезпечують виконання законодавства України у сфері інформаційних відносин, виконання державних і регіональних програм у цій сфері;

органи місцевого самоврядування - затверджують регіональні та місцеві програми розвитку інформаційної сфери, бюджети в цій сфері;

інші державні органи й організації: Державний комітет статистики України, Державне патентне відомство України, Концерн радіомовлення, радіозв'язку і телебачення тощо; засоби масової інформації - це вся діяльність, що спрямована на інформування населення, формування громадської думки та громадянського суспільства;

політичні партії, громадські організації, професійні спілки, заклади академічної науки та освіти, неурядові дослідницькі організації, інші організації й установи - діють відповідно до завдань їхньої діяльності в системі забезпечення інформаційної безпеки України.

Висновки. Отже, виходячи з проаналізованих наукових наробок, можна визначити такі головні складники забезпечення інформаційної безпеки держави:

1. Правове забезпечення - визначення складу, послідовності й порядку розроблення нормативно-правових актів з питань інформаційної безпеки, а також механізмів уведення їх у дію;

2. Науково-технічне забезпечення - це створення інформаційної бази, яка допоможе реалізувати концепцію інформаційної безпеки України і створити цільову науково-технічну програму забезпечення інформаційної безпеки;

3. Організаційне забезпечення - це розроблення і створення організаційної структури системи інформаційної безпеки України, створення системи сертифікації технічних і програмних засобів інформації на відповідність вимогам інформаційної безпеки;

4. Ресурсне забезпечення - це забезпечення системи захисту інформаційної безпеки кадрами, матеріально-технічними й фінансовими коштами.

\section{Література}

1. Вітер С.А., Світлишин І.І. Захист облікової інформації та кібербезпека підприємства. Економіка та суспільство. 2017. № 11. С. 497-502.

2. Марущак A.І. Інформаційно-правові напрями дослідження проблем інформаційної безпеки. Державна безпека України. 2011. № 21. С. 92-95.

3. Северина С.В. Інформаційна безпека та методи захисту інформації. Вісник Запорізького національного університету. 2016. № 1 (29). С. 155-161.

Рогова $\epsilon$. I., аспірантка Університету державної фіскальної служби України 